
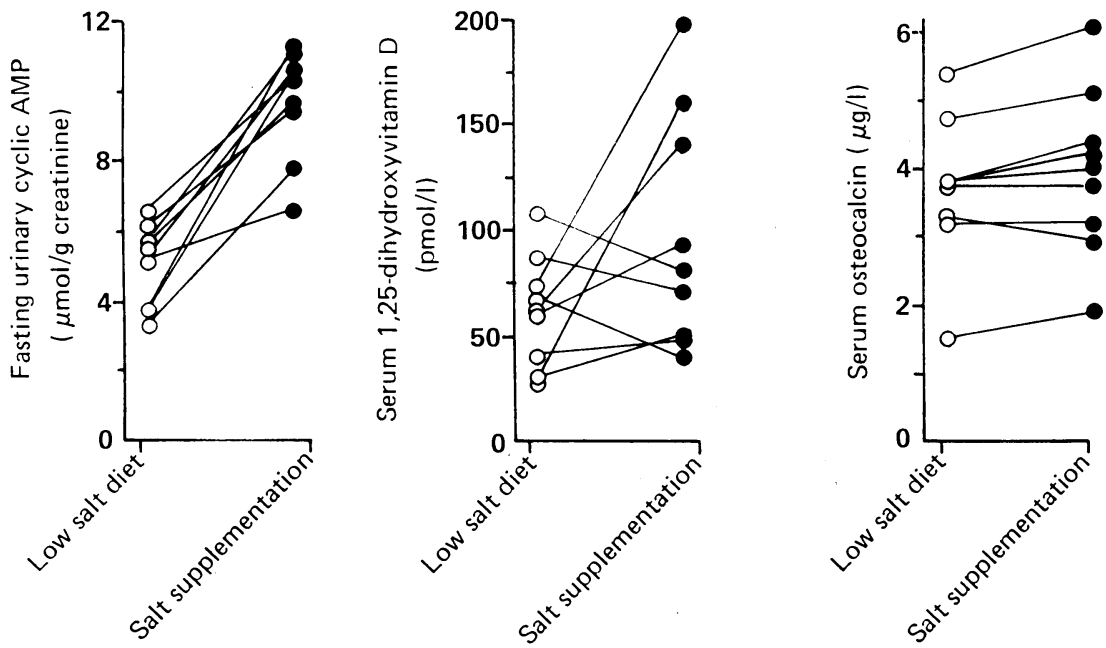

Urinary cyclic AMP excretion and serum 1,25-dihydroxyvitamin D and osteocalcin concentrations during low salt regimen and salt supplementation in nine healthy volunteers

Osteocalcin was measured by radioimmunoassay (Incstar Corporation, Minnesota) in a single assay of serum stored at $-80^{\circ} \mathrm{C}$ (coefficient of variation $=4 \cdot 2 \%$, $\mathrm{n}=10$ ). All other measurements were by standard techniques.' Significance (low salt regimen $v$ salt supplementation) was assessed with a two tailed paired $t$ test.

During salt supplementation 24 hour urinary sodium excretion rose from 70 (14) to 167 (25) $\mathrm{mmol}$ $(\mathrm{p}<0.001)$, calcium from $2.08 \quad(0.73)$ to 2.65 $(0.88) \mathrm{mmol}(\mathrm{p}<0.001)$, and hydroxyproline from 158 (42) to $217(69) \mu \mathrm{mol}(\mathrm{p}<0.05)$ but creatinine did not change (rising from $9.3(1.5)$ to $9.9(1.5) \mathrm{mmol}$ ). Absorption of strontium did not increase (the proportion of the administered dose in extracellular fluid rose from $9 \cdot 0(3 \cdot 1)$ to $9 \cdot 3(3 \cdot 1) \%)$. The figure shows urinary cyclic AMP excretion and serum 1,25-dihydroxyvitamin $\mathrm{D}$ and osteocalcin concentrations; mean values rose from $5.0(1 \cdot 1)$ to $9 \cdot 7(1 \cdot 6) \mu \mathrm{mol} / \mathrm{g}$ creatinine $(\mathrm{p}<0.001), 61.9(26.4)$ to $98.6(55.9) \mathrm{pmol} / \mathrm{l}$, and $3.7(1 \cdot 1)$ to $4.0(1 \cdot 2) \mu \mathrm{g} / 1(\mathrm{p}<0.05)$, respectively.

When the subjects took their normal diet 24 hour urinary sodium excretion (109 (28) $\mathrm{mmol})$, calcium $(2 \cdot 24(1 \cdot 0) \mathrm{mmol})$, hydroxyproline $(179(88) \mu \mathrm{mol})$, and creatinine $(9.7(1.4) \mathrm{mmol})$ were intermediate between the values obtained during the low salt regimen and salt supplementation.

\section{Comment}

Moderate variations in dietary salt intake influenced variables of resorption and formation of bone in elderly women. The rise in hydroxyproline excretion indicated increased resorption of bone due to increased parathyroid activity. ${ }^{13}$ The increased urinary cyclic AMP excretion indicated raised parathyroid hormone concentrations. The small rise in osteocalcin concentration indicated increased formation of bone. ${ }^{+}$ Changes in osteocalcin concentration mediated by salt have not been reported previously.

Breslau et al reported a significant increase in 1,25-dihydroxyvitamin D concentrations in young subjects given salt loads but no increase in older women with osteoporosis. ${ }^{5}$ In our study 1,25dihydroxyvitamin D concentrations increased, though not significantly. Our index of alimentary absorption of calcium (absorption of strontium) did not rise. Increased 1,25-dihydroxyvitamin D concentration probably triggered the small rises in osteocalcin concentration we observed. ${ }^{+}$Alternatively, some unidentified factor(s) coupling resorption and formation of bone may have been responsible.

Women who lose bone shortly after the menopause have a net negative calcium balance of about $1.0 \mathrm{mmol} / \mathrm{day}$. In our study modest supplementation with salt raised urinary calcium excretion by $0.57 \mathrm{mmol} /$ day. Because calcium requirements will be lower with low salt intakes, decreasing salt intake should benefit the skeletons of women susceptible to type II (senile) osteoporosis.

This work was supported by bequest funds to Otago Medical School and by the Medical Research Council of New Zealand. The Otago Hospital Board ethical committee approved the protocol

1 Goulding A. Everitt HE, Coones JM, Spears GFS. Sodium and osteoporosis. In: Truswell AS, Walqvist ML, eds. Recent advances in clinical nutrition. In: Truswell AS, Walquist ML, eds. Recent

2 Milsom S, Ibbertson HK, Hannon S, et al. Simple test of intestinal calcium absorption measured by stable strontium. Br Med f 1987;295:231-4

3 Breslau NA, McCiuire JL, Zerwekh JE, Pak CYC. The role of dietary sodium on renal excretion and intestinal absorption of calcium and on vitamin D metabolism. I Clin Endocrinol Metab 1982;55:369-73.

Lian JB, Gundberg CM. Osteocalcin. Biochemical considerations and clinical applications. Clin Orthop 1988;226:267-91.

5 Breslau NA, Sakhaee K, Pak CYC. Impaired adaptation to salt-induced urinary calcium losses in postmenopausal osteoporosis. Trans Assoc Am Physicians 1985:98:107-15.

Accepted 26 fune' 1989)

\title{
Overtreatment of children with Wilms' tumour outside paediatric oncology centres
}

\section{Hospital for Sick Children, Great Ormond Street, London WC1H 3JH \\ J Pritchard, FRCP, consultant in oncology}

Childhood Cancer

Research Group, Radcliffe Infirmary, Oxford

OX2 6HE

C A Stiller, MSC, research officer

E L Lennox, MB, research officer

Correspondence to: Dr Pritchard.

\section{J Pritchard, C A Stiller, E L Lennox}

The main clinical objective of research into cancer is to identify the minimum treatment necessary for cure to reduce the impact of toxicity. By 1979, in a series of randomised trials, the United States national Wilms' tumour study had established that $(a)$ patients with stage I disease in whom the histological appearance indicates a favourable prognosis do not need abdominal radiotherapy and need at most six months' chemotherapy with two drugs, vincristine and actinomycin $\mathrm{D} ;(b)$ those with stage II tumours with a favourable prognosis need a maximum of 20 Gy hemiabdominal radiotherapy and 15 months' chemotherapy with the two drugs; and $(c)$ those with operable stage III disease with a favourable prognosis need 10-20 cGy abdominal or hemiabdominal radiation and 15 months' treatment with vincristine, actinomycin $\mathrm{D}$, and adriamycin. In the first two studies over $90 \%$ of children in these three categories survived free of disease more than five years after diagnosis and were presumed to be cured.'

The first study of Wilms' tumour by the United Kingdom Children's Cancer Study Group started in 1979 and incorporated several refinements of treatment, some derived from results of the Medical Research Council's second trial ${ }^{2}$ - for example, besides surgery only vincristine was used in patients with stage I disease in whom the histological appearance indicated a favourable prognosis. Only children in whom the histological appearance indicated an unfavourable prognosis and those with stage IV tumours (a fifth of the total) received abdominal radiation of $>20 \mathrm{~Gy}$ and intensive chemotherapy.

In another study children with Wilms' tumour treated outside paediatric oncology centres during 1977-84 had a similar overall survival to that of children managed elsewhere, ${ }^{3}$ but some seemed to have received more treatment than was appropriate. The present study assessed treatment of British children 


\begin{tabular}{|c|c|c|c|c|c|}
\hline \multirow[b]{2}{*}{$\begin{array}{l}\text { Case } \\
\text { No }\end{array}$} & \multirow[b]{2}{*}{$\begin{array}{l}\text { Clinical } \\
\text { stage }\end{array}$} & \multirow{2}{*}{$\begin{array}{l}\text { Prognosis } \\
\text { based on } \\
\text { histological } \\
\text { appearance }\end{array}$} & \multirow{2}{*}{$\begin{array}{c}\text { Dose of } \\
\text { radiotherapy } \\
\text { postoperatively } \\
\text { (cGy) }\end{array}$} & \multicolumn{2}{|l|}{ Chemotherapy } \\
\hline & & & & Drugs given & $\begin{array}{l}\text { Duration } \\
\text { (months) }\end{array}$ \\
\hline 1 & I & Favourable & Unknown & Vincristine & Unknown \\
\hline 2 & I & Favourable & None & Vincristine, adriamycin & 12 \\
\hline 3 & I & Unfavourable & 3500 & Vincristine, actinomycin D & 13 \\
\hline 4 . & I & Favourable & 2400 & Vincristine, actinomycin D & 12 \\
\hline 5 & II & Favourable & 3900 & Vincristine, actinomycin $\mathrm{D}$, adriamycin & Unknown \\
\hline 6 & II & Favourable & 3000 & Vincristine, actinomycin D & Unknown \\
\hline 7 & II & $\star \star$ & 3150 & Vincristine, actinomycin D & 15 \\
\hline 8 & III & Favourable & 3250 & Vincristine, actinomycin D, adriamycin & 22 \\
\hline 9 & III & $t$ & $2325 \ddagger$ & Yincristine, actinomycin D, adriamycin & 15 \\
\hline 10 & III & Favourable & 3000 & Vincristine, actinomycin D & 14 \\
\hline
\end{tabular}

* Specimen inadequate for histological review, but prognosis originally reported as favourable. †Histological appearance could not be reviewed as specimen obtained after chemotherapy. $\ddagger$ Dose of 1675 cGy given preoperatively.

with Wilms' tumour in centres that were not in the United Kingdom Children's Cancer Study Group; the study was of treatment during three years contemporary with the group's first study of Wilms' tumour.

\section{Patients, methods, and results}

Patients with Wilms' tumour diagnosed in 1980-2 but not treated in centres in the United Kingdom Children's Cancer Study Group were identified from the population based national registry of childhood tumours. Histopathological appearances of the tumours were reviewed centrally. Ten of the 30 children identified had been entered into the study group's first trial of Wilms' tumour. Of the remainder, 10 had received substantially more treatment than was recommended in that trial (table). Three children with stage I tumours (cases $1,3,4)$ had received radiotherapy. Three with stage II tumours (cases 5, 6, 7) and three with stage III tumours (cases $8,9,10$ ) had received more radiotherapy than would have been prescribed in the study group's first trial. Similarly, two children with stage I tumours (cases 2 and 4 ) and two with stage II tumours (cases 5 and 7 ) had received more drugs or longer chemotherapy than necessary. The three year survival rate for these 20 children was $65 \%$ compared with $82 \%$ for the 170 children treated contemporaneously in the study group's first trial or at a paediatric oncology centre (log rank test: $\chi^{2}=2 \cdot 23$, $\mathrm{p}>0 \cdot 1)$.

\section{Comment}

We found that 10 of the 20 children we studied had received more treatment that we would recommend. Although abdominal radiotherapy is generally well tolerated by children, it has several serious effects. Within the field of treatment growth of bone and soft tissue is decelerated, particularly in very young children. The risk of sterility and second malignancy is also increased, ${ }^{+}$and perinatal mortality and the rate of low birthweight infants are increased in women given abdominal radiotherapy during childhood. Side effects of chemotherapy increase with the cumulative dose.

All children with cancer, including those with a comparatively good prognosis, should initially be referred to tertiary centres for inclusion in multicentre studies. Once the diagnosis, stage of disease, and treatment have been established care can be shared with a nearby paediatric unit. This approach reduces the child's distress and minimises the social, economic, and medical costs of treatment.

We are grateful to all the consultants and registries who supplied information and material for this study; Professor H B Marsden for reviewing the histology; and Professor G J d'Angio for editorial comment. Sue Medhurst and Sheila Giles provided secretarial help. The Childhood Cancer Research Group is supported by the Department of Health and the Scottish Home and Health Department, the United Kingdom Children's Cancer Study Group by the Cancer Research Campaign, and JP partly by the Imperial Cancer Research Fund.

1 D'Angio GJ, Beckwith JB, Breslow NE, et al. Wilms' tumour: an update. Cancer 1980;45:1791-8.

Jones PM, Marsden HB, Pearson D. The conclusion of the 2nd MRC nephroblastoma study [Abstract]. Arch Dis Child 1983;58:653.

3 Stiller CA. Centralisation of treatment and survival rates for cancer. Arch Dis Child 1985;60:1097.

+ Hawkins MM, Draper GJ, Kingston JE. Incidence of second primary tumours among childhood cancer survivors. Br f Cancer 1987;56:339-47.

Li FP, Gimbrere K, Gelber RD, et al. Outcome of pregnancy in survivors of W'ilms' tumor. FAMA 1987:257:216-9.

(Accepted 19 fune 1989
Sandhead and Glenluce, Stranraer

A G Baird, MRCGP, general practitioner

J C M Gillies, MRCP, general practitioner

N T Miscampbell, $\mathrm{MB}$, trainee general practitioner

Dumfries and Galloway Royal Infirmary, Dumfries F J Bone, FRCPATH, consultant microbiologist B A S Dale, MRCPATH, consultant microbiologist

Correspondence to: Dr A G Baird, The White House, Sandhead, Stranraer, Wigtownshire DG9 9JA.

BrMed f 1989;299:836-7

\section{Prevalence of antibody indicating Lyme disease in farmers in Wigtownshire}

\section{A G Baird, J C M Gillies, F J Bone, B A S Dale, N T Miscampbell}

Lyme disease is caused by the spirochaete Borrelia burgdorferi. Its association with erythema chronicum migrans and arthritis has been recognised in the United States since '1975,' and the infection is also associated with neurological disease, such as meningitis (acute and chronic) and neuritis (cranial and peripheral). Sporadic cases of erythema chronicum migrans have occurred for many years in Scotland. ${ }^{2}$ The vector of the disease in the United Kingdom is the tick Ixodes ricinus, which is widespread in Scotland.

Lyme disease was diagnosed in a patient in this practice in association with acute purulent meningitis, during which seroconversion occurred, though the patient's cerebrospinal fluid was not tested for Lyme disease. ${ }^{3}$ His complete recovery from an apparently hopeless progressive illness after antibiotic treatment prompted us to survey others at risk in our practice.

\section{Patients, methods, and results}

Serum samples were examined from 108 patients aged 15 years and over, 101 of whom were selected because of their potential exposure to ticks. They included farmers, foresters, and gamekeepers. The remaining seven patients were selected because of illness potentially attributable to Lyme disease.

Serum samples were examined initially by immunofluorescence with commercially prepared slides (Lyme disease antibody test system, Zeus). Samples positive for the antibody at titres $\geqslant 128$ were matched with those negative for the antibody from patients matched by age and sex and retested by the microbiology department, Charing Cross Hospital, by a different immunofluorescence test for IgG and IgM antibodies and an enzyme linked immunosorbent assay (ELISA) system specific for $B$ burgdorferi antibody.

Twelve patients had antibody to $B$ burgdorferi, none of whom were positive for antibodies to Treponema pallidum, Leptospira spp, or Listeria monocytogenes. Eleven patients of the 12 on close questioning had symptoms possibly attributable to infection with 